
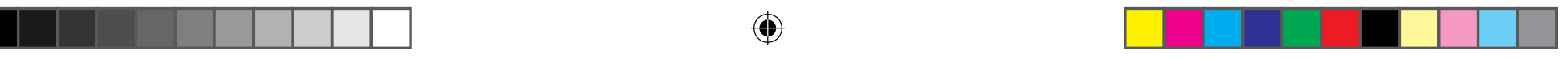

\title{
A GLIMPSE OF KELANTANESE MAK YONG FROM THE PAST TO THE PRESENT
}

\author{
CHONG LEE SUAN, * \\ TONY RUDYANSJAH** \\ leesuan@umk.edu.my
}

\begin{abstract}
Abstrak
Kajian ini bertujuan untuk meneroka sejarah Mak Yong Kelantan secara ringkas dan melihat beberapa perubahan sepanjang dekad sebelum ia merosot secara beransur-ansur pada abad ke-20. Penulisan ini bermula dengan pengenalan ringkas Mak Yong Kelantan dan kemudian mengesan pengaruh animisme dan Islam yang menentukan perubahan kontekstual dan kandungan cerita dalam persembahan Mak Yong. Dalam keadaan di mana Mak Yong menghadapi kekurangan pewaris, kekurangan penghibur, dan larangan dari prinsip dan undang-undang Islam, seni warisan ini tidak lagi diamalkan sebagai sebahagian dari rutin hiburan dalam kampong dan jalinan kerjasama di antara penggiat Kelantan dan Terengganu Mak Yong menjadi intim dan diperlukan. Untuk terus hidup, ia perlu mencari penyelesaian untuk menyesuaikan rangka konsep animisme-Islam dengan tafsiran semula daripada bomoh yang berpengetahuan dalam spiritual.
\end{abstract}

Kata Kunci: Mak Yong, Seni Warisan Kelantan, Warisan Dunia UNESCO

* Pensyarah di Fakulti Teknologi Kreatif dan Warisan, Universiti Malaysia Kelantan, Malaysia

** Pensyarah Kanan dan Ketua Jabatan Antropologi, Universitas Indonesia 


\begin{abstract}
This study intends to briefly explore the past of Kelantanese Mak Yong and look into several changes throughout the decades before it gradually declines in the 20th century. The paper begins with a brief historical introduction of Kelantanese Mak Yong and later traces the animistic and Islamic influences that determine the contextual changes and story contents in Mak Yong performances. In a situation where Mak Yong faces the possible discontinuation of heirs, insufficiency of performers, and obstruction from Islamic principles and laws, the art is no longer practiced as part of the village entertaining routine and the collaboration between Kelantanese and Terengganuan Mak Yong performers becomes intimate and needed. To survive, it needs to resolve for an adaptation of animistic-Islamic conceptual settings with reinterpretations from the spiritually knowledgeable bomohs.
\end{abstract}

Keywords: Mak Yong, Kelantanese performing arts, UNESCO world heritage

* Lecturer at Faculty of Creative Technology \& Heritage, University Malaysia Kelantan

** Senior Lecturer and Head Department of Anthropology at Universitas Indonesia

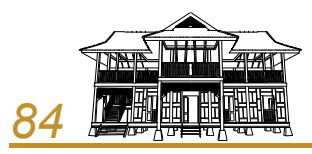




\subsection{Introduction}

Kelantan is believed to be the place where Mak Yong was first originated during the time even before the state was under the reign of Patani. Mak Yong was later brought from the Patani region - a kingdom stretching from southern Thailand through Kelantan and Terengganu - further to Kedah and the Riau Islands of Indonesia (Figure 1). This traditional art was handed down orally through the generations, whose teachings were memorised by a handful of actors, musicians, and comedians. Today, In Kelantan villages, there are not many Mak Yong traditional performers surviving from the Seri Gabus and Arjuna Sastera Bahu Groups, with a few others being free individuals.

\subsection{Historical Accounts}

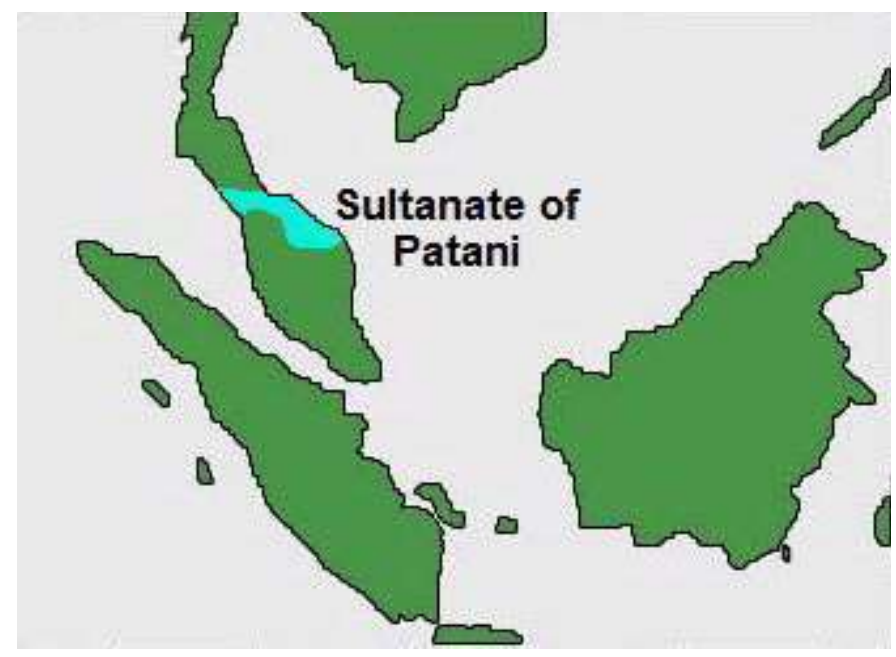

Figure 1: A map of the Sultanate of Patani that covers modern day Kelantan and Patani.

Photo source: Taken with the consent of Creative Commons Attribution-Share Alike 4.0 International License.

The shamanistic nature of Mak Yong suggests its ancient connection to the time when animism existed. It is estimated to date before the arrival of Hinduism in Kelantan in the 3rd century where a small Hindu Kingdom of Pan Pan was said to exist in the modern day areas of Kelantan and Terengganu, as mentioned by Munoz (2006) in the Early Kingdoms of the Indonesian Archipelago and the Malay Peninsula. Mak Yong was developed at an early stage from animistic beliefs in a natural living environment in contact with spiritual beings. This explains the spiritual elements of Mak Yong that heals or performs along with the animistic rituals and possession of spirits. 

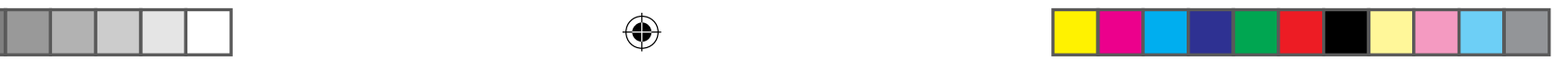

Few scholars, such as Ghulam Sarwar Yousof (1976), Mubbin Sheppard (1974), A. Teeuw, and D. Wyatt (1970), attempted to trace the origin of Mak Yong. Nonetheless, it has not been proven whether Mak Yong originated in the folk traditions or the royal entertainment theatres. However, both versions of its origin remain alive in the traditions of Mak Yong. Different philosophical theories and historical stories were found among the Kelantanese and Terengganuan Mak Yong, dispersed mainly by prominent Mak Yong performers and their surviving lineages. The Mak Yong stories are divided into two lineages in both states: Histories of Kelantanese and Patani Kings, and legends of Gods based primarily on Islam and animism. The Sri Temenggong group surviving in Terengganu holds to their unbroken lineage of story lines recording the lives of Kelantanese and Patani Kings, as they believe that Mak Yong was created by an official entertainer in the palace telling the stories of the kings. Later, Tengku Temenggong Abdul Ghaffar established the Kampung Temenggong before the Second World War to provide a theatre house for royals to enjoy the performing arts such as Mak Yong, Wayang Kulit, and others. Hence, the chronicles of the kings remain within Mak Yong stories in Sri Temenggong group. Other Mak Yong groups in Kelantan and Terengganu were found to be influenced by animism, where they chose to fill in stories of heavenly beings and magical interferences.

Mak Yong reached its glory during the 1950s to 1980s. From the 1980s, it started to deteriorate until today, where there are less than ten Mak Yong performers still surviving in Kelantan, with a few Besut Mak Yong performers in Terengganu who are closely related to the Kelantan Mak Yong groups. Although Mak Yong was proclaimed "a cultural masterpiece" by UNESCO, under the Oral and Intangible Heritage of Humanity awarded on November 25, 2005, it has been listed as a banned traditional art form together with Menora by the state government of Kelantan since 1990, given its nature that contradicts Islamic principles. The nature of Mak Yong's origin in the pre-Islamic period that encourages the worship of entities beside Allah has added to the reason for the ban. Others would be the issue of no boundary socialisation and promiscuity that go against eastern and Islamic values. These result in a faster decline in the efforts to preserve Mak Yong in Kelantan. Today, there is limited interest in Mak Yong among the young Kelantanese, as the young children are now not interested and most of them do not understand the stronger accents of the old Kelantanese dialect. In addition, it is very hard to earn a stable living by holding Mak Yong as an occupation. From the perspective of older Mak Yong performers, it is hard to find a youngster nowadays with angin of Mak Yong who truly possesses the deep passion and connection with the art. 

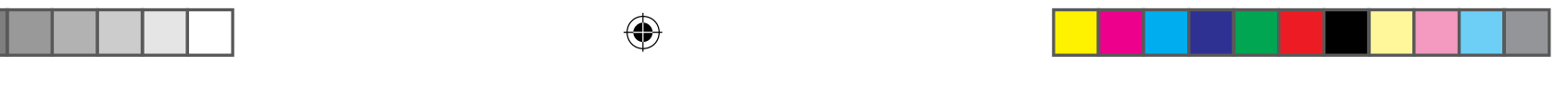

\subsection{Surviving Performers and Terengganuan Collaboration}

In Kelantan, treasured traditional Kelantanese Mak Yong performers can be found in places like Bachok, Machang, Pasir Mas, Pasir Puteh, Tumpat, and Wakaf Baru, where most of them are veterans over 50 years old. The surviving recognised and experienced traditional Mak Yong perfomers in Kelantan are Wan Midin Bin Wan Majid (Pak Wan Midin), Nisah Binti Mamat (Mek Nisah), Aminah Binti Hussain (Mek Timah), Rahimah Binti Zakaria (Mek Mah), Bakar Bin Awang (Pak Bakar), Siti Aishah Binti Mottok, Rohani Binti Husin, and Mat Agel Bin Mat Daud (Pak Agel) (Figure 2).

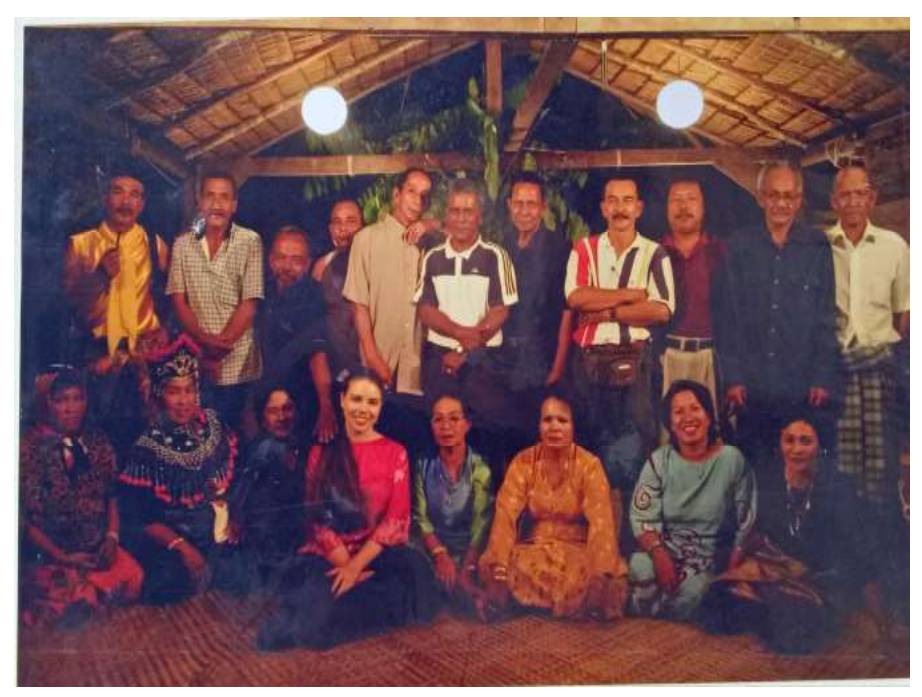

Figure 2: Pak Agel (back row, left 1), Pak Su Kadir (back row, left 5), Mak Su Siti (front row, left 2), Mek Nisah (front row, left 3), American researcher - Patricia A. Hardwick (front row, left 4), Mek Timah (front row, right 1).

Photo: courtesy of Patricia A. Hardwick and Mak Su Siti.

Besut, Terengganu, which was once belonged to the Kelantanese Sultanate, has nurtured a few elder Mak Yong main role performers, such as the renowned Che Siti Binti Dollah, Abdul Kadir Bin Dollah, Mek Jah Binti Deris and Muhammad @ Mohd Nor Bin Salleh. Elderly performers from Kelantan have for years performed Mak Yong alongside the surviving popular Sri Temenggong group (a lineage rooted in Kelantan) and the Chempaka Willis group, both from Besut, Terengganu. Today, Kelantanese Mak Yong groups work very closely with Besut (Northern Terengganu) Mak Yong 

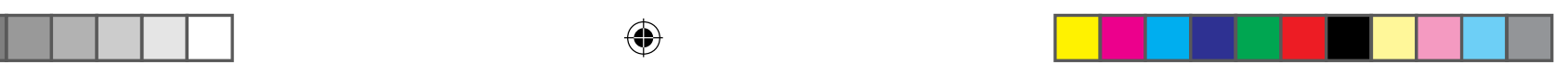

groups. Both lineages often perform together as there are not enough Mak Yong performers in each state as are needed in a performance. The dialect used in Kelantan is very similar to the one spoken in Northern Terengganu due to geographical factors. In particular, people from Besut, a district of Terengganu located near the border with Kelantan, interact actively with Kelantanese residents. Moreover, the Mak Yong stories performed in both states are very similar. This enables and eases collaboration, and also indicates the close connections and influences between them.

This collaboration began more than ten years ago and became stronger during the peak of Mak Yong and after its honourable recognition by UNESCO in 2005. The groups from the two states were invited by the Malaysian Ministry of Tourism and Culture and private agencies to hold performances in Brazil, Indonesia, England, France, Singapore, South Africa, Spain, and Thailand. Siri Neng Buah, who originated from Kelantan and was awarded the National Heritage Living Person Award in 2013, previously held the position of Director in Department of Intangible Heritage, National Heritage Council (Jabatan Warisan Negara), and had contributed immensely to support, promote, and preserve the art of Mak Yong in Kelantan and Terengganu. Unfortunately, he passed away recently in April 2017 (Figure 3).

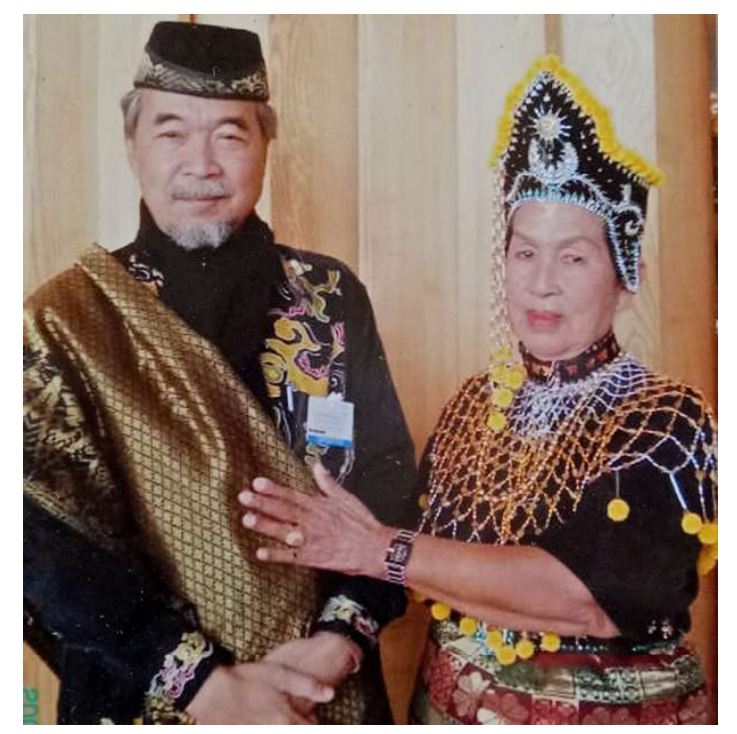

Figure 3: Siri Neng Buah (left) with Mak Su Siti (right) performing in France in conjunction with the Campaign of Bandar Melaka and Georgetown as World Heritage Sites.

Photo: courtesy of Mak Su Siti. 

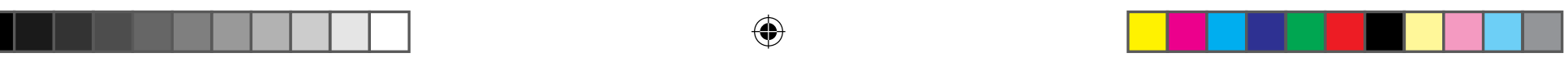

\subsection{The Bomohs and Their Roles}

The Seri Gabus and Arjuna Sastera Bahu Groups, from Pasir Mas and Pasir Puteh, were respectively led by Wan Midin Bin Wan Majid (Pak Wan Midin) and Mat Agel Bin Mat Daud (Pak Agel). These two groups are the only surviving Mak Yong groups in Kelantan. The others remain to be the independent individuals as their groups have died out. Both Pak Wan Midin and Pak Agel are the bomohs or healers who are able to perform the prayers and healing rituals in Mak Yong performances, besides being the drummers, and perans 1 or the comedic court servants. Given the nature of Mak Yong as not just for entertainment purposes, but also as a healing ritual, the bomohs will be called to perform the baca doa or baca kenduri at the beginning session, buka panggong, of the performance as the cleansing ceremony to politely request the spirits not to disturb the performance, as well as to pray (combining both animistic and Islamic ways) for blessings and protections from the God and to begin the healing process if the Mak Yong performance is performed for healing (Figure 4 and Figure 5). According to the life experiences of the Mak Yong performers, spirits often like to intrude on the villagers during performances such as Mak Yong, Wayang Kulit, and Dikir Barat. It is believed that spirits like to interact with people when people's moods are heightened during the entertaining performances.

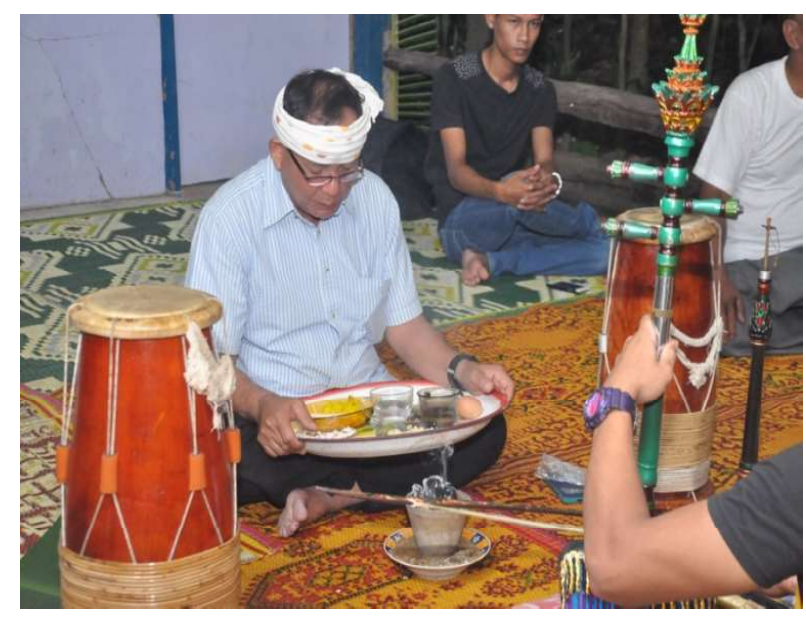

Figure 4: A Bomoh opens a Mak Yong Performance with the Doa Kenduri Ritual.

Photo: Research Team.

1 Peran is a character that plays comical roles and a host of other supporting roles. 

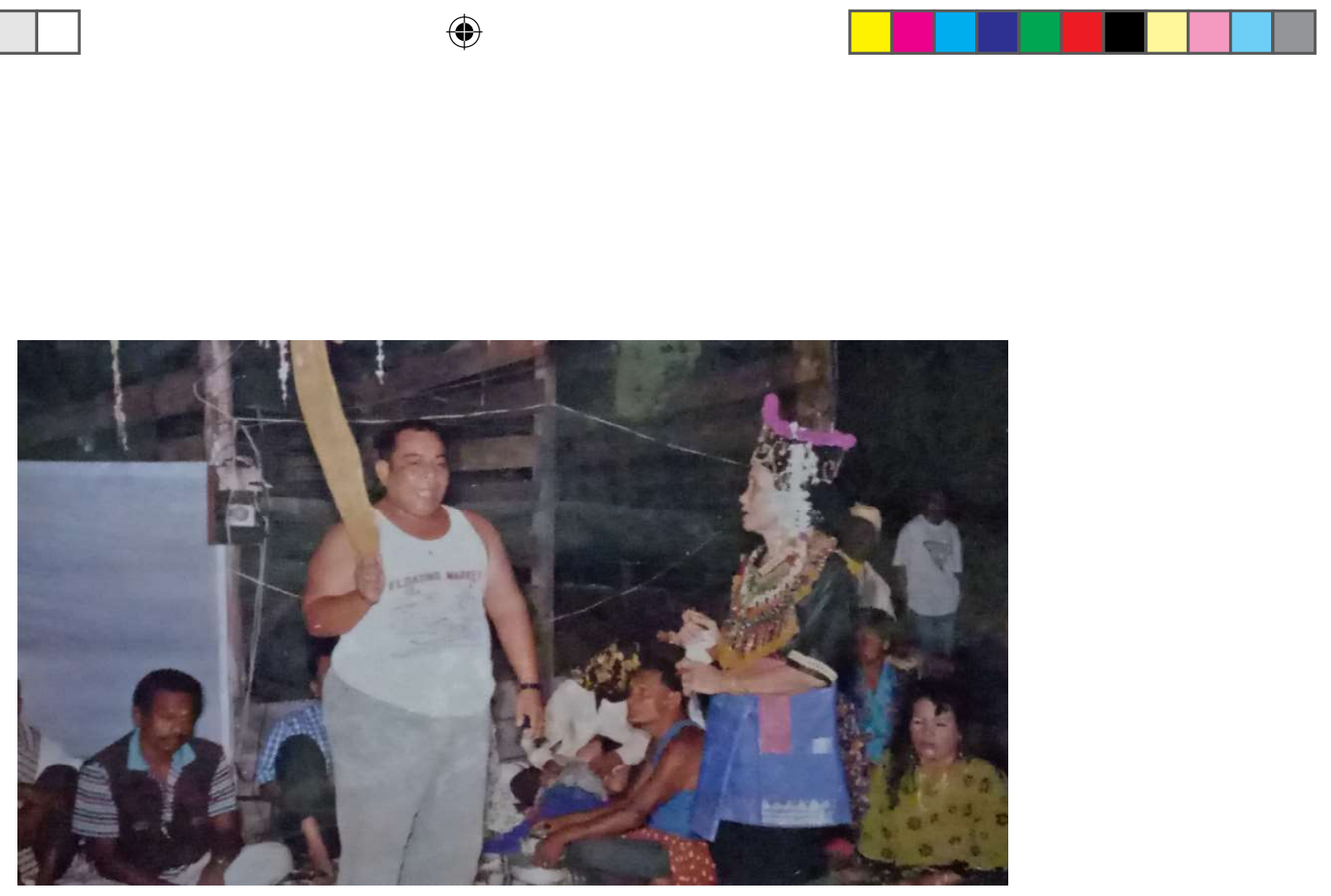

Figure 5: Bomoh (left) healing the patient (right, in Pak Yong costume) in Main Teri-Mak Yong ritual.

Photo: courtesy of Rahimah binti Zakaria.

Since the past, the bomohs have worshipped spiritual beings which are known as sakas 2 that will be inherited to the bomohs' heirs. As each bomoh follows different guru, their experiences and interpretations about the spirituality of Mak Yong and their ways to handle the rituals differ slightly from each other. Each bomoh practices his own mantras or spells transmitted down by his guru and often has specific connections with certain spiritual beings. They are able to either see, feel or communicate with the spirits. The bomohs are not merely healers, yet with their extraordinary spiritual knowledge, today they are usually the leaders or the tradition keepers of Mak Yong. These leaders are conferred the opportunity and power to sculpt the philosophy and structural contents of Mak Yong rituals, stories and performances.

2 Saka is a spirit that stays with or follows a person and it is usually inherited for generations.

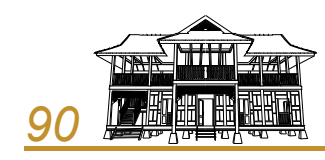



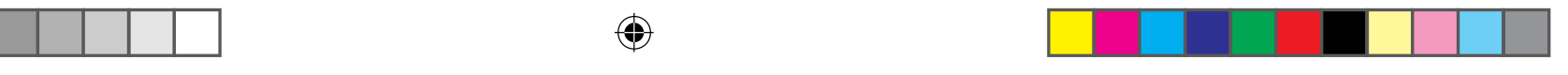

Dewa Muda and Dewa Pechil are the two main stories performed since the past to the present. The stories are commonly performed together with the Main Peteri3 ritual to heal the sick patients. According to Pak Agel, the character of Dewa Muda symbolises what is within a person - lust, while the character of Dewa Pechil is believed to be outcast - the placenta, which is the filth right at the moment of the birth of a baby. Dewa Muda is intertwined with Dewa Pechil serving to control lust, the essence of Dewa Muda. Both Dewa Muda and Dewa Pechil were born siblings from the same womb. As a bomoh, Pak Agel's lineage believes Dewa Pechil exists in the supernatural form considered to be an "outsider". Meanwhile, Dewa Muda manifests as a human in the real world who possesses lust. It is very interesting that Pak Wan Midin expressed his different views saying that his guru had never told the similar story. He was taught that the Dewa Muda indeed symbolizes "lust" and is the brother of Dewa Pechil. In the teachings of his lineage, there are all together seven brothers who lived in heaven but only Dewa Pechil and Dewa Pechil came to the mundane world and manifested as the kings. Different views are found very common among different bomohs since the ancient time as the bomohs received transmission or were bestowed spiritual power from different spiritual sources and sacred animistic texts. The differences have not brought about any controversial issues among the Mak Yong practices. In contrary, the diversity enriches the contextual creativity of Mak Yong stories and performances and reflects the multitudinous beliefs and spiritual experiences of the villagers.

The bomohs have also played the important roles to reinterpret today's Mak Yong after it is banned. The worshipping of other spiritual beings beside Allah is prohibited in Islamic teachings. The rationales of Islam point out that since the spiritual beings do not possess the similar ultimate holy nature and wisdom as the God and they are lower beings created by the God, it is obviously not wise to follow those beings that are not able to show the humans a right spiritual path. Today, the Muslims Malay bomohs adapt the Islamic principles in their Mak Yong practices by changing their motivations and texts in the prayers. Instead of worshipping the spirits, the bomohs begin their prayers with Arabic recitations of praise to Allah: 'In the name of Allah, The Most Gracious and The Most Merciful'. This is followed by the recitation of the last three chapters of the Holy Quran; for the purpose of seeking protection from Allah as "The Almighty", "The Cherisher and Sustainer of the worlds", "Lord and Cherisher of Mankind" and "Lord of Dawn". The healers then continue with an ancient animistic cyclical genealogy in Kelantanese dialect of the gods and demi-gods, holding the Allah as the supreme power, politely summoning the spirits to not interrupt but to guard the performance space. This genealogy begins and ends with Dewa Sev Ale Tunggal [The Only God of the Universe], implying that all the other mythological figures named are but aspects of this Supreme Being (Hardwick, 2009:69-73). This is an alternative to allow the Muslim Mak Yong practitioners to continue their tradition and fulfil the needs of their people under such an underprivileged living environment they have to cope with in the villages.

3 Main Peteri or Main Teri is a Kelatanese healing ritual conducted by Tok Minduk and Tok Teri (the bomohs) to cure the sick patients. It is normally practiced in the villages. 


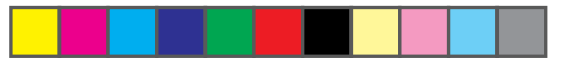

\subsection{Conclusions}

Mak Yong remains to be a form of performing art developed by Malay communities in the villages pertaining to their cultural and religious values ever since the oldest Mak Yong performers could remember. Communal ties and unity are essential social values to develop peace and happiness in Malay village communities. Mak Yong stories bear the ancestors' aspirations to educate their people about good values in life, especially to strengthen the ties of brotherhood and to cultivate affection and harmony among the villagers. This can be presented through warm and casual performance settings, where the audience sit and mingle closely with each other and with the performers during the performance, as well as through the stories that relate good advices, values and guidance of life. It is a way to bring about care, unity, and happiness to their lives in the villages.

From the past until the present, Kelantanese Mak Yong has evolved gradually struggling to survive yet still preserve its essential values. There are obvious signs foreseeing its extinction in the future. However, the practitioners still persist to accommodate Mak Yong in the modern life - only because the art brings no serious harms but some necessary and important benefits that cannot be compensated by other contemporary performing arts.

\section{Acknowledgements}

This research would not have been possible without the financial support of the Malaysia Ministry of Higher Education Fundamental Research Grant Scheme (FRGS). Our research team would like to extend sincere gratitude for the help and assistance given by surviving Mak Yong activists in Kelantan and Terengganu especially Pak Wan Midin (Wan Midin Bin Wan Majid), Mek Nisah (Nisah Binti Mamat), Pak Siri (Siri Neng Buah), Pak Su Roni (Muhammad @ Mohd Nor B. Salleh), Mek Jah Deris (Mek Jah Binti Deris), Mak Su Siti (Che Siti Binti Dollah), Pak Kadir (Abdul Kadir Bin Dollah), Aminah Binti Hussain, Pak Agel (Md. Gel Bin Mat Dali) and Kak Rahimah (Siti Aishah Binti Muttok). 


\section{References}

Ghulam-Sarwar Yousof. (1976). The Kelantan Mak Yong Dance Theatre: A Study of Performance Structure. PhD Dissertation, University of Hawaii, Honolulu, Hawaii.

Ghulam-Sarwar Yousof. (1983). Buka Panggung: Theatre Consecration Rituals in the Mak Yong Dance Theatre of Kelantan, Malaysia. Tenggara 16: 55-72.

Ghulam-Sarwar Yousof. (2011). Mak Yong Theatre of Kelantan, Malaysia: An Introduction. Kuala Lumpur: The Asian Cultural Heritage Centre.

Ghulam-Sarwar Yousof. (2017). The Mak Yong Dance Theatre as Spiritual Heritage: Some Insights. SPAFA Journal Vol 1, No 1: 1-9.

Hardwick, Patricia Ann. (2009). Stories of The Wind: The Role of Mak Yong in Shamanistic Healing in Kelantan, Malaysia. PhD Thesis. Indiana University, October.

Malm, WP. (1971). Malaysian Ma'yong Theatre. The Drama Review 15: 108-144.

Munoz, P. M. (2006). Early Kingdoms of the Indonesian Archipelago and the Malay Peninsula. Singapore: Editions Didier Millet.

Sheppard, M. (1969). The Text of The Sung Portion of Dewa Muda And A Further Note On Ma'yong Stories. Federation Museums Journal 14: 45-74.

Sheppard, Mubin. (1974). Ma'Yong, the Malay dance-drama. In Mohd Taib Osman (ed.) Traditional Drama and Music of Southeast Asia, 35-46. Kuala Lumpur: Dewan Bahasa dan Pustaka.

Teeuw, A., \& Wyatt, D. (1970). Hikayat Patani. The story of Patani. The Hague: Martinus Nijhoff. 
